\title{
Differences in richness and composition of gastrointestinal parasites of small rodents (Cricetidae, Rodentia) in a continental and insular area of the Atlantic Forest in Santa Catarina state, Brazil
}

\author{
Kuhnen, VV. ${ }^{a *}$, Graipel, ME. ${ }^{b}$ and Pinto, $C J C .^{a}$ \\ ${ }^{a}$ Laboratório de Protozoologia, Departamento de Microbiologia, Imunologia e Parasitologia, \\ Universidade Federal de Santa Catarina - UFSC, CP 476, CEP 88010-970, Trindade, Florianópolis, SC, Brazil \\ bProjeto Parques e Fauna, Departamento de Ecologia e Zoologia, Universidade Federal de Santa Catarina - UFSC, \\ CEP 88010-970, Trindade, Florianópolis, SC, Brazil \\ *e-mail: vanessavk@ig.com.br
}

Received April 4, 2011 - Accepted December 9, 2011 - Distributed August 31, 2012

(With 2 figures)

\begin{abstract}
The first and only study on gastrointestinal parasites of wild rodents in the Island of Santa Catarina was done in 1987. The aim of this study was to identify intestinal parasites from wild rodents in Santo Amaro da Imperatriz and Santa Catariana Island, and to compare the richness and composition of the gastrointestinal parasite community of both areas. Rodents were captured with live traps, and feces were screened using the sedimentation method and optical microscopy. The following species of rodents were captured in the two areas: Akodon montensis, Euryoryzomys russatus, Oligoryzomys nigripes and Nectomys squamipes. In Santo Amaro da Impetratriz, prevalent parasites were: A. montensis (51\%), E. russatus (62\%), O. nigripes (53\%) and N. squamipes (20\%). From the Island of Santa Catarina the rodent prevalence rates were: A. montensis (43\%), E. russatus (59\%), O. nigripes (30\%) and N. squamipes (33\%) and the collected parasites were: Hymenolepis sp., Longistriata sp., Strongyloides sp., Hassalstrongylus sp., Syphacia sp., Trichomonas sp., Ancylostomidae, Trichuridae, Oxyuridae and Eucoccidiorida. The species richness (10.6 \pm 0.7$)$ of the endoparasite comunity in the area located on the continent was higher $(\mathrm{p}<0.01)$ and different $(\mathrm{p}=0.001)$ from that of the area located on the island $(6.9 \pm 0.5)$.
\end{abstract}

Keywords: Biogeography, Desterro Environmental Conservation Unit, Serra do Tabuleiro State Park.

\section{Diferenças na composição e na riqueza de parasitas gastrointestinais de pequenos roedores (Cricetidae, Rodentia) em uma área continental e uma insular de Floresta Atlântica em Santa Catarina, Brasil}

\section{Resumo}

Parasitas gastrointestinais de roedores silvestres foram estudados pela primeira vez na Ilha de Santa Catarina em 1987. Desde então, nenhum outro estudo nessa área foi realizado no Estado. O objetivo do presente estudo foi identificar parasitas intestinais de roedores silvestres de Santo Amaro da Imperatriz e da Ilha de Santa Catarina, bem como comparar a composição e a riqueza da comunidade de parasitas gastrointestinais de ambas as áreas. A análise das fezes dos animais capturados foi realizada por meio do método de sedimentação espontânea (HJP) e por microscopia óptica. Nas duas áreas, foram capturadas as espécies de roedores Akodon montensis, Euryoryzomys russatus, Oligoryzomys nigripes e Nectomys squamipes. Em Santo Amaro da Impetratiz, observou-se a seguinte prevalência de parasitoses: A. montensis (51\%), E. russatus (62\%), O. nigripes (53\%) e N. squamipes (20\%). Diferentemente, em Florianópolis, as frequências de parasitoses foram: A. montensis (43\%), E. russatus (59\%), O. nigripes (30\%) e N. squamipes (33\%). Os parasitos encontrados pertencem aos grupos: Hymenolepis sp., Longistriata sp., Strongyloides sp., Hassalstrongylus sp., Syphacia sp., Trychomonas sp., Ancilostomatidae,Trichuridae, Oxyuridae e Eucoccidiorida. Foi possível observar que os roedores da área localizada no continente (Santo Amaro da Imperatriz) possuem uma comunidade de parasitas gastrointestinais mais rica $(10.6 \pm 0.7 ; \mathrm{p}<0.01)$ e diversa $(\mathrm{p}=0.001)$ do que a comunidade presente na Ilha de Santa Catarina $(6.9 \pm 0.5)$.

Palavras-chave: Biogeografia, Unidade de Conservação Desterro, Parque Estadual da Serra do Tabuleiro. 


\section{Introduction}

In Tropical Forests, small mammals play an important role in balancing the ecosystem. In particular, rodents contribute directly to the dynamics and energy exchange of ecosystems: they act as predators, prey, and primary consumers as well as contribute to plant ecology in the dispersal of seeds (Lima et al., 2001). As a result of their habits, behaviour and habitat, they are predisposed to infection by parasites (Catto, 2000).

Demographic studies suggest that parasitic infections are one of the mechanisms that regulate small mammalian population sizes. Some parasite species are able to reduce the fertility and survival rates of their hosts as the degree of infection increases, thereby participating in the regulation process of rodent populations (Spratt, 1990). However, different types of parasites, with different life cycles, or diversely pathogenic, play markedly different roles (Combes, 1996).

Mas-Coma and Montoliu (1987) and Mas-Coma et al. (1988) have both shown that the pressures exerted by parasites on their hosts are different on islands, with respect to the nearby continent. An example is a study of 1968 on three species of small mammals of the island of Skomer (Lewis 1968a, b) that found that there were fewer parasite species in the island populations of the three host species than in the mainland populations.

In Brazil, some studies have been conducted on parasitic diseases of wild rodents (e.g. Gomes and Vicente, 1984; Gomes et al., 2003; Dall'Olio and Franco, 2004; Souza et al., 2006). However, considering their ecological importance, there are only a few that focus on the biodiversity of parasites of small mammals. The study of Vicente et al. (1987) is the only survey on endoparasitic fauna of mammals in the Atlantic Forest region of Santa Catarina Island. After their study no research on the subject has been conducted in the area.

Thus, the aim of this study was to describe and compare the endoparasites of different wild rodent species from two different regions of the Atlantic Rainforest, in the cities of Florianópolis, located on the island of Santa Catarina and Santo Amaro da Imperatriz, located on the continent and lying along the same latitude in the state of Santa Catarina, Brazil.

\section{Material and Methods}

\subsection{Study site}

The study was conducted in the Atlantic Forest of Santa Catarina state, southern Brazil, in two reservations: Desterro Environmental Conservation Unit (DECU) (490 ha; $27^{\circ}$ $52^{\prime} \mathrm{S}$ and $48^{\circ} 50^{\prime} \mathrm{W}$ ), located in the central region of the Island of Santa Catarina (Florianópolis); and in a section of the Serra do Tabuleiro State Park (STSP) (5000 ha; $27^{\circ}$ $44^{\prime} \mathrm{S}$ and $48^{\circ} 48^{\prime} \mathrm{W}$ ), located in the city of Santo Amaro da Imperatriz in the continent.

The two study areas are $40 \mathrm{~km}$ apart from each other, but both have very similar climates, vegetation and topography.
The predominant vegetation type is the Atlantic Rainforest (Dense Ombrophilous Forest) (Veloso et al., 1991). The climate is subtropical with high annual rainfall $(1800 \mathrm{~mm})$. Altitudes range from 420 to $1100 \mathrm{~m}$, and the mean annual temperature varies between $20^{\circ} \mathrm{C}$ and $24{ }^{\circ} \mathrm{C}$ in January and $12{ }^{\circ} \mathrm{C}$ and $16^{\circ} \mathrm{C}$ in July in both areas (Gaplan, 1986).

\subsection{Data collection}

Between March 2005 and August 2006, 24 samplings were done on three consecutive nights each month. The animals were captured with Young live traps $(260 \times 120 \times 90 \mathrm{~mm})$. A transect with 80 capture stations, $20 \mathrm{~m}$ apart from each other, was installed on the ground in each sampled area. Traps were baited with banana slices covered with peanut butter.

Feces of animals captured in the traps were collected with tweezers and stored in properly labeled Eppendorf ${ }^{3}$ tubes containing a preserving solution (sodium acetate, acetic acid, formaldehyde $40 \%$ and distilled water) (Yang and Scholten, 1977). Feces were sedimented by the Hoffman's method (Hoffman et al., 1934) and analysed by optical microscopy. Eggs or cysts of parasites were identified based on their morphology (Vicente et al., 1997; Rondon, 2010).

\subsection{Data analysis}

To estimate parasite richness in each of the sampled areas, we used the Smith and van Belle (1984) equation with the nonparametric bootstrap resampling method of 1000 replications of random screenings and replacements (Friedman and Friedman, 1995). The Fisher exact test (Zar, 2009) was used to compare the parasite richness of the two areas. The community composition of the parasites in the two sampled areas was compared using the similarity analysis (ANOSIM), based on the similarity index of Sorensen (Clarke and Warwick, 2001).

\section{Results}

Seventy-five wild rodents were captured in the continental area and 65 were captured in the insular area (Table 1). The rodent species Akodon montensis (Thomas, 1913), Oligoryzomys nigripes (Olfers, 1818), Euryoryzomys russatus (Wagner, 1848) and Nectomys squamipes (Brants, 1827) were captured in both areas. Sooretamys angouya (Fischer, 1814) and Oxymycterus judex (Thomas, 1909) were captured only in the continent. In total, ten different parasites species were recorded in the two sampled areas (Figure 1).

The parasite richness calculated for the continent $(10.6 \pm 0.7)$ was higher $(\mathrm{p}<0.01)$ than that calculated for the island $(6.9 \pm 0.5)$ (Figure 2). The composition of the endoparasitic community was also different in the two sampled areas $(\mathrm{p}=0,001)$. The parasites Hassalstrongylus sp., Hymenolepis sp. and Ancilostomatideo were recorded in both areas. Longistriata sp., Strongyloides sp., Trichomonas sp. and Eucoccidiorida were only recorded in rodents of the continent, whereas Syphacia sp., Oxyuridae and Trichuridae were only found in the island. 


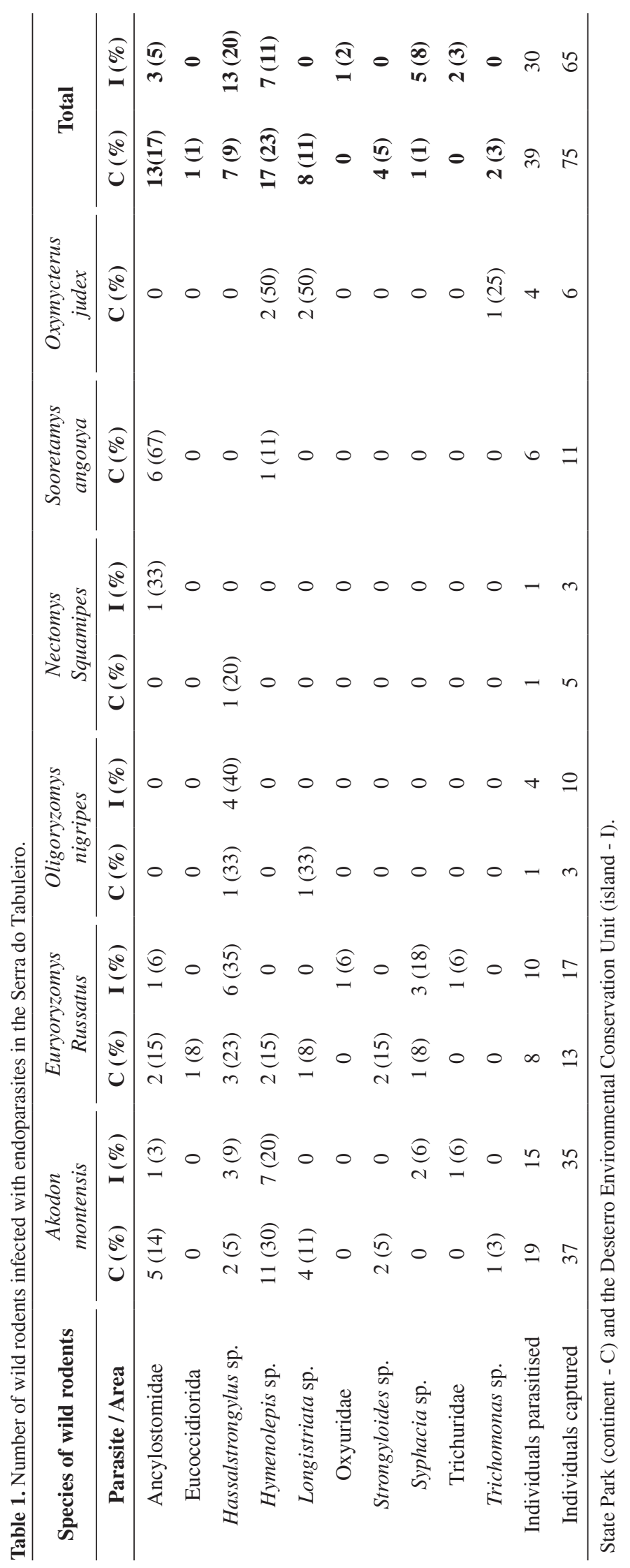


Thirty-seven $A$. montensis were captured in the continent and $51 \%$ were positive for some parasite. Six different parasites were found, and the most common were Hymenolepis sp. (30\%) and Longistriata sp. (11\%). Thirty-five A. montensis were captured in the island, in which $43 \%$ were parasitised. Five different parasites were found, and the most common were Hymenolepis sp. (20\%) and Hassalstrongylus sp. (9\%).

We captured 13 individuals of the E. russatus species in the continent, and $62 \%$ were parasitised. Seven different parasites were found, and the most common was the Hassalstrongylus sp. (23\%). Seventeen E. russatus were captured in the island, and $59 \%$ were positive carrying five different parasite species. The most common parasites were Hassalstrongylus sp. (35\%) and Syphacia sp. (18\%).

Three $O$. nigripes were captured in the continent and only one was positive, with the Longistriata sp. and Hassalstrongylus sp. species. Of the ten $O$. nigripes captured in the island, four were found to have parasites, all infected by Hassalstrongylus sp..

Five individuals of the $N$. squamipes species were captured in the continent. Of these, only one was positive, with the Hassalstrongylus sp. parasite. Of the three $N$. squamipes captured in the island only one was parasitised by the Ancylostomidae.

Four of the six individuals of S. angouya, also captured only in the continent, were positive. All were parasitised by Ancylostomidae and only one individual was parasitised by Hymenolepis sp.. Sixty-seven percent of the 11 individuals of the $O$. judex species, captured only in the continent, were positive, and $50 \%$ of the individuals were parasitised by Hymenolepis sp.

\section{Discussion}

Our results contribute to the knowledge of the helminthic fauna of small rodents in the state of Santa Catarina, being the first study of gastrointestinal parasites of the continental area of the State of Santa Catarina, and adding new information to that provided by the previous work of Vincente et al. (1987) in the Island of Santa Catarina.

Vincente et al. (1987) examined 41 rodents of the genus Akodon (probably A. montensis), Oxymycterus (probably $O$. aff. judex), and Oligoryzomys nigripes. Two parasite species were identified: Litomosoides carinii and Hassalstrongylus zetta. In our study we also registered the genera Hassalstrongylus, for the same rodent species (Oligoryzomys nigripes) collected by Vicent et al. (1987). Despite having occurred in both areas, this genus was more frequently found on the island.

Some helminth genera collected in this study had been previously found in the same rodent species in other Brazilian states. For example, the genus Hassalstrongylus and Syphacia were detected in the rodent species $N$. squamipes by Gomes et al. (2003) and Gomes and Vincente (1984), both in Rio de Janeiro state.

Although parasites were not identified to their species level, we obtained six different taxa of parasites for the sampled area on Santa Catarina Island. This demonstrates the wide variety of parasites in wild rodent species of the Island. For the continental area of Santa Catarina state, this is the first study about small rodents and their endoparasites. Adding our results to those species identified by Vicent et al. (1987), Santa Catarina state has now at least 11 recorded endoparasite species of small wild rodent host species.

The lower values of richness and diversity of the community composition of parasites on Santa Catarina Island when compared to those of the mainland may be correlated with various factors, such as habitat size, body size, population density and/or geographic range of the host (Poulin and Morand, 2000). Despite the fact that the continental area had two more host species (Sooretamys angouya and Oxymycterus judex) than the island area, these rodent species did not host any exclusive parasite species. Therefore, further studies to clarify the different causes of the pressures faced by the parasite species of islands in comparison to those faced by parasite species of the mainlands are needed.

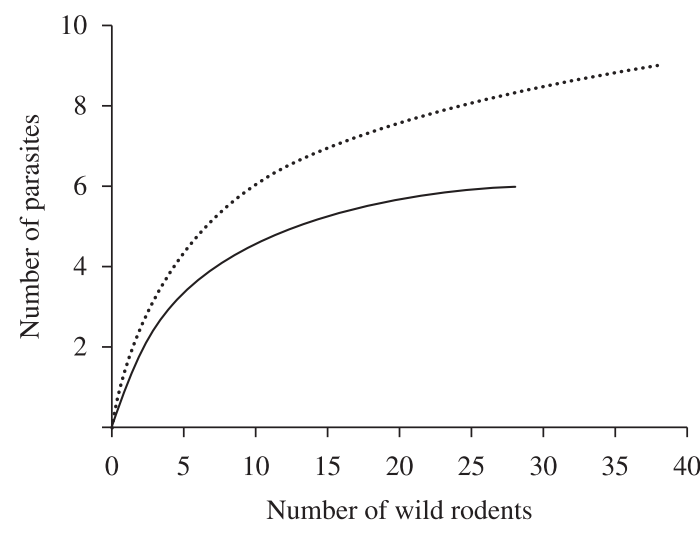

Figure 1. Rarefaction curve for the number of parasites identified in the two sampled areas (Legend: dotted = Serra of Tabuleiro State Park; solid = Desterro Environmental Conservation Unit).

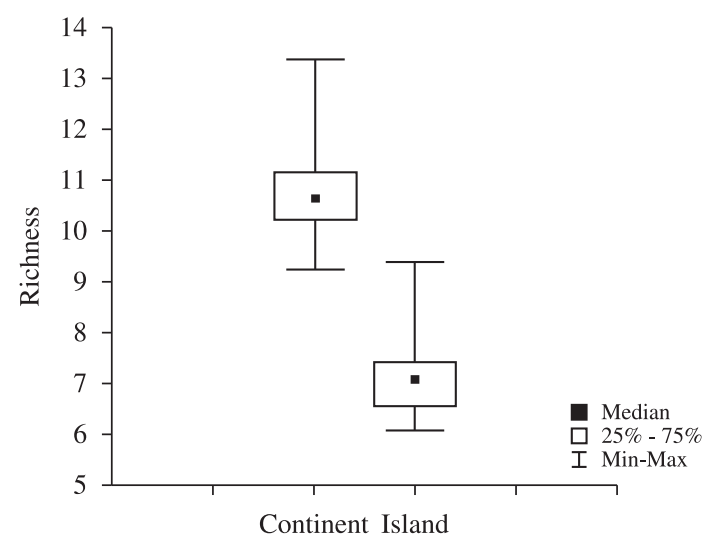

Figure 2. Richness estimates by the Smith and van Belle index obtained by bootstrap re-sampling for the sites in Santo Amaro da Imperatriz (Continent) and in Florianópolis (Island). 
Euryoryzomys russatus was the only rodent that hosted unique parasite species (Eucoccidiorida in the continent and Oxyuridae in the island). This result can be regarded as evidence of specificity in parasite/host relationships in the target areas. Nevertheless, considering the low prevalence of these parasites this could also be just a matter of sampling effort. However, as no parasite was found in all captured rodent species, this could also be regarded as evidence of host specificity of the parasitic organisms of the target areas.

Currently there is poor available data on host specificity in the parasite species of wild animals. Survey data on parasites in wild rodents is essential to generate information on the occurrence of different parasite groups. We hope that the data presented in this paper contributes to the understanding of the ecology of parasites in wild rodents, filling the gap that still prevails.

Acknowledgements - We are very grateful to UFSC and FATMA for allowing the field research at Desterro Environmental Conservation Unit and at Serra do Tabuleiro State Park, respectively. Thank you very much Pâmela Castro Antunes and Thiago Thales Moreira for the opportunity. We also thank Plaza Caldas da Imperatriz Resort for the scholarship of VVK and logistic support. Thank you Rafael Schroeder, Humber A. de Andrade and Fernando P. Mayer for helping with the statistical analysis, and Eduardo Torres for improving the manuscript.

\section{References}

CATTO, JB., 2000. Endoparasitos de animais domésticos e silvestres do Pantanal: helmintos, acantocéfalos, pentastomídeos e protozoários. In Anais do $3^{\circ}$ Simpósio sobre Recursos Naturais e Sócio Econômicos do Pantanal, 2000. Corumbá: Embrapa. Available from: <http://www.cpap.embrapa.br/agencia/congresso/ Bioticos/CATTO0088.pdf>. Access in: dec. 2000.

CLARKE, KR. and WARWICK, RM., 2001. Change in marine communities: an approach to statistical analysis and interpretation. 2nd ed. United Kingdom: PRIMER-E Plymouth. 159 p.

COMBES, C., 1996. Parasites, biodiversity and ecosystem stability. Biodiversity and Conservation, vol. 5, p. 953-962. http://dx.doi. org/10.1007/BF00054413

DALL'OLIO, AJ. and FRANCO, RMB., 2004. Ocorrência de Cryptosporidium spp. em pequenos mamíferos silvestres de três áreas serranas do Sudeste brasileiro. Arquivo Brasileiro de Medicina Veterinária e Zootecnia, vol. 56, p. 25-31.

FRIEDMAN, LW. and FRIEDMAN, HH., 1995. Analyzing simulation output ssing the bootstrap method. Simulation, vol. 64, n. 2 , p. $95-100$. http://dx.doi.org/10.1177/003754979506400203

GAPLAN, 1986. Atlas de Santa Catarina. Florianópolis: Gabinete de Planejamento e Coordenação Geral. 173 p.

GOMES, DC. and VICENTE, JJ., 1984. Helmintos parasitos de Nectomys squamipes (Brants) do Município de Sumidouro, R.J. Memórias do Instituto Oswaldo Cruz, vol. 79, p. 67-73.

GOMES, DC., CRUZ, RP., VICENTE, JJ. and PINTO, RM., 2003. Nematode parasites of marsupials and small rodents from the Brazilian Atlantic Forest in the state of Rio de Janeiro, Brazil. Revista Brasileira de Zoologia, vol. 20, p. 699-707. http://dx.doi. org/10.1590/S0101-81752003000400024

HOFFMAN, WA., PONS, JA. and JANER, JL., 1934. The sedimentation concentration method in Schistosomiasis mansoni.
Puerto Rico Journal of Public Health and Tropical Medicine, vol. 9, p. 283-298.

LEWIS, JW., 1968a. Studies on the helminth parasites of the long-tailed field mouse, Apodemus sylvaticus sylvaticus from Wales. Journal of Zoology, vol. 154, p. 287-312.

-, 1968b, Studies on the helminth parasites of voles and shrews from Wales. Journal of Zoology, vol. 154: 313-331.

LIMA, M., JULLIARD, R., STENSETH, NC. and JAKSIC, FM., 2001. Demographic Dynamics of a neotropical small rodent (Phylotis darwini): feedback structure, predation and climatic factors. Journal of Animal Ecology, vol. 70, p. 761-775. http:// dx.doi.org/10.1046/j.0021-8790.2001.00536.x

MAS-COMA, S. and MONTOLIU, I., 1987. The life cycle of Dollfusinus frontalis a brachylaimid trematode of small mammals (Insectivora and Rodentia). Internatinoal Journal for Parasitology, vol. 17, p. 1063-79.

MAS-COMA, S., GALAN-PUCHADES, MT., FUENTES, MV., VALERO, MM. and JIMENEZ, AM., 1988. Sobre la composición cuantitativa de las parasitofaunas insulates: posible efecto regulador de las especies parasitas sobre las poblaciones de sus hospedadores. In SANS-COMA, V., MAS-COMA, S. and GOSALBEZ, J., eds. Mamiferos y Helmintos. Barcelona: Ketres Editora. p. 217-251.

POULIN, R. and MORAND, S., 2000. The diversity of parasites. The Quarterly Review of Biology, vol. 75, n. 3, p. 277-293. PMid:11008700. http://dx.doi.org/10.1086/393500

RONDON, MVSS. 2010. Biodiversidade de parasitas intestinais em mamíferos silvestres de duas localidades do estado de São Paulo. Campinas: Universidade Estadual de Campinas. 160 p. Tese de Doutorado em Parasitologia.

SMITH, EP. and VAN BELLE, G., 1984. Non parametric estimation of species richness. Biometrics, vol. 40, p. 119-129. http://dx.doi. org/10.2307/2530750

SOUZA, JGR., OLIVEIRA, RP., RODRIGUES, SR. and MALDONADO JUNIOR, A., 2006. Helmintofauna de pequenos roedores da Mata Atlântica, Teresópolis, Rio de Janeiro. In: Livro de resumos do I Congresso Sul Americano de Mastozoologia, 2006. Gramado. p. 98.

SPRATT, DM., 1990. The role of helminth in the biological control for mammals. International Journal for Parasitology, vol. 20, p. 543-550. http://dx.doi.org/10.1016/0020-7519(90)90202-X

VELOSO, HP., RANGEL FILHO, ALR. and LIMA, JCA., 1991. Classificação da vegetação brasileira adaptada a um sistema universal. Rio de Janeiro: IBGE, Departamento de recursos naturais e estudos ambientais. $124 \mathrm{p}$.

VICENTE, JJ., RODRIGUES, HO., GOMES, DC. and PINTO, RM., 1997. Nematóides do Brasil. Parte V: Nematóides de mamíferos. Revista Brasileira de Zoologia, vol. 14, p. 1-452.

VICENTE, JJ., SCHLEMPER JUNIOR, BR., RODRIGUES, HO., STEINDEL, M. and PADOVANI, CR., 1987. Contribuição ao conhecimento da fauna helmintológica de mamíferos da Ilha de Santa Catarina, SC. Atas da Sociedade de Biologia do Rio de Janeiro, vol. 27, p. 5-8.

YANG, J. and SCHOLTEN, T., 1977. A fixative for intestinal parasites permitting the use of concentration and permanent staining procedures. American Journal of Clinical Pathology, vol. 67, n. 3, p. 300-304. PMid:65913.

ZAR, JH., 2009. Biostatistical analysis. 5th ed. New Jearsey: Pearson Prentice Hall. 944 p. 
